\title{
New Audience Message Absorption via Audio Visual Technology
}

\author{
Mohd. Nor Shahizan Ali ${ }^{1}$, Latiffah Pawanteh ${ }^{1}$, Normah Mustaffa ${ }^{1}$, Hasrul Hashim ${ }^{1}$ \& Abdul Latiff Ahmad ${ }^{1}$ \\ ${ }^{1}$ University Kebangsaan Malaysia, Malaysia \\ Correspondence: Mohd. Nor Shahizan Ali, University Kebangsaan Malaysia, Malaysia. E-mail: \\ shahizan@ukm.my
}

Received: February 16, 2013 Accepted: March 29, 2013 Online Published: April 25, 2013

doi:10.5539/ass.v9n8p107

URL: http://dx.doi.org/10.5539/ass.v9n8p107

\begin{abstract}
The diversity of audio visual technology has its own effect to audience to obtain message through formal and informal education. Arguably, having acquired such ability, an individual will be able to absorb various media messages. This research seeks to redefine model of audience evolution that proposed by The Donald McGannon Communication Research Center of new audiences by adding an audio visual technology as a meaning-making components in the interpretation of portal web television. The concept of audio visual technology was further developed by adding conceptualization of meaning making in interpreting media messages. This research assumes that audio visual technology input can be exposed and the skills can be transferred to the respondent in a formal setting. The researcher seeks to identify the relevance of audio visual technology in raising the level and capacity of new audience absorbs message. The significance between the audio visual technology via the meaning-making components and the increasing level of new audience absorbs message. A total of 80 first-year media students from University Kebangsaan Malaysia were randomly selected to participate in the experiment. The students were divided into two respective groups, the treatment and the control. Only the treatment group was exposed to audio visual selected interactivity queues such as selected programs, comment, chat rooms and online quizzes. Both groups were later shown online portal web TV (tonton.com.my) that produced by Media Prima Group. The selection of this online portal web TV is justified in it being the first online TV portal that fixed in all Media Prima's TV station. Findings from the experimental method discovered that students in both groups showed different levels of new audience absorbs message. Findings revealed that individual interpretation of the online portal web TV was dependent on time-binding factors such as experience, knowledge and education as well as the unique cultural conditioning of each individual. The findings of this study suggested that the audio visual technology meaning making component is the distinguishing element for model of audience evolution introduced by The Donald McGannon Communication Research Center in the absorbs message of the new audiences.
\end{abstract}

Keywords: audiences, meaning making, audio visual, information technology, portal web

\section{Introduction}

Information is the most importance for human being and it's not a new requirement since human's existence until now. There is a difference in the context of time and how information is communicated to the audience and how the communication activity takes place. Compatible with time, recent communication activities more focused on the use of technology. According to Albarran (2006), Chatterji (2006), Mullen (2005) and Southwell (2005), technology is an element that contributes to the development of a country because the ability to channel information, activities and communication networks between organizations.

Technology development is one of the main factors that led to a change in media organizations in the country. According to Bucy \& Newhagen (2004), Grant (1996), Noor Bathi (2002) and Verser \& Wicks (2006) the changes is a form of paradigm that changed the effect of making the public no longer questions about how to obtain the information, but the discussion is centered to the medium in the selection of information. For example, the using of media from print to electronic media as a source had a major change in access to information for the community. Accordingly, various efforts undertaken in the form of further research to identify any technology that can have an impact and how it can provide the maximum information required (Bucy \& Newhagen, 2004; Grant, 1996; Noor Bathi, 2002; Verser \& Wicks, 2006).

Flood of information through various mediums can influence the audience whether information or character of an 
information. Dissemination of information becomes simpler in many forms such as text, graphics, audio and graphics through various mediums that emerged in tandem with technology development. When the spread of information exchange to the more simple form, it makes it difficult to interpret to the audience in all the information disseminated (Potter, 2011). This view was concurring by Harris (2006) who gives the view that the visual is the most important element in communication systems since the beginning. He added that people communicate with each other by using the visual before they developed and civilized. These visually convey their message to the next generation. Using visual presentations has grown in tandem with technological developments. Starting from a variety of visual painted on cave walls to the visual changes that are emitted through the television and computer (Harris, 2006).

The objective of this research is to identify the relevance of audio visual technology in raising the level and capacity of new audience absorbs message. This objective will proof the effected of audio visual technology to new audience message interpretation.

\section{Literature Review}

Katz and Blumber (1974), suggests that the real audience are the most active and have a specific goal when using any media. They make their own choices through a variety of resources to meet the satisfaction of use. Developments in technology with the explosion of globalization also provide variety of resources to the public, especially the emergence of new media like the Internet. Ruggiero (2000), also argues that new media like the Internet has at least three new satisfaction measure than traditional media, the value of interactivity, the ability to choose and continuous communication. Audience is actually independent of the choice of media they want on their level of satisfaction to be enjoyed. However, due to technological change, especially in terms of media and communications, the audience is actually formed by the media (Napoli, 2008). The Donald McGannon Research Center stated that there are three factors that led to this change in the evolution of media, media and audience fragmentation and public autonomy.

The development of this technology has resulted in changes to changes in the process the message. Increase amount of information in various forms (text, graphics, audio and visual) in tandem with the development of this technology has affected the quality and character of each transmitted information. Year after year the pattern of changing information presented based on the interests of any information presented. More simple with a combination of information each element (text, graphics, audio and visual) more closely to the target recipients of the information (Potter, 2011).

Whiting (2001) and agreed by Thoman \& Jolls (2004) states that the use of visual information delivered in the visible can help to ensure that all information submitted will meet the target groups in line with existing technology. Use visual basic research by Thoman \& Jolls (2004) show that the information communicated through the visual can help target groups carefully evaluate, classify information in order of importance, to judge and help in decision making and are an appropriate process to avoid the information misinterpreted by the recipient.

Creeber (2009) consider that the development of the old media to new media in connection with the concept of modernism and postmodernism. Audience modernization process actually intertwined with the development of mass media according to the period in question. Modernism saw the rise of novel culture, cinema, television, comics, newspapers and radio as a tool for development and the audience of that time until the lead up to the postmodernism is more focused on understanding, audience's thinking and meaning interpretations and the emergence of popular culture as well as providing a critical new arena in understanding new media like the Internet.

Phrase 'narrowcasting' used to describe new media audiences are chiefly also gives details of the role of radio and television in the development of technology (Stober, 2004). Interactivity is the world audience in the context of new media also allows the audience to 'publisher' and at the same time as the recipient.

In Malaysia, the development of the broadcasting system along with the line of social development audience. As early as the development, the role played by television in particular to modernize its society seems very large impact (Karthigesu, 1994). This includes the process considerably impact social (social institutionalizing) that lead to changes in media creation through new forms of communication such as changes in the conventional media to new media, Internet (Stober, 2004). World broadcasting in this country not only limited to television broadcasting alone but has expanded to publication through the website or portal, better known as television stations.

In the context of digital broadcasting era, technological advances seen as a form of development opportunities to a better level than before. According to Fuziah Kartini et al. (2004) labeled the digital era as Infomedia in conjunction with the form that propels the dominant technology. This evolution has consistency changed the media 
landscape from time to time and this development is known as mediamorfosis. This term refers to the evolution of technology and media communication transformed to new media (Fidler, 1997).

Transitional form of broadcasting to the Internet proved that the Internet provides greater satisfaction than other media (Valkenburg \& Soeters, 2001). As a multifunctional medium, a combination of media such as television, books, radio and video games make it more popular among youngsters and teenagers. The study by Baran (2010) shows the transition of broadcast television stations in the U.S. are turned to the implications of online consumers and marketing. The study suggests three elements that must exist within the portal web television station, which is a balance of content, appropriateness of the size and content to be marketed in the marketability of the business profits while providing a win-win situation with the audience.

Baran (2010) also thought-leading pioneer of traditional media, especially broadcast media such as television to improve their understanding and perspectives on the Internet not only as a merger of the new media but also as a form of a strategic tool in getting more audience and also the advantages. Thus, the merger of two medium broadcast on televisions and the Internet actually provides advantages not only to audiences but also gives an advantage to the station. Television stations also need to make full use of Internet technology to present the message is trying to convey to the audience that the level of satisfaction achieved by the public could be improved.

\section{Meaning Making}

As described by Duck \& Shotter (in Wood, 2004: 19), the construction of meaning during the process of interaction with others and through dialogue in our thinking is also a symbolic process because we depend on words in mind to think about the meaning. Thus, according to Wood (2004) audience as active users interpret the symbols in the incident, situation, experience and relationships. Audience using symbols to designate, assess, respond, share experiences, ideas, and feelings. While for Harvey Graff, defining the concept of literacy has long been debated over the years involving the merger of several areas such as politics, culture, and education agenda is not just focused on understanding audiences. This discussion has exceeded that for this concept held by the traditional understanding of literacy just put pen and paper as changes to the digital era and structuring information is also subject to change (Potter, 2011).

In reality, audio visual information economic distribution and level of achievement got high demand over the world. This means that the public is more interested in obtaining information from media based on audio visual than the text (Friedmann, 2001; Harris, 2006; Kress, 2003). Thus, the role of audio-visual materials to convey information to the community is important. Unfortunately, the question of how to give meaning to the audio-visual materials in making the interpretation is not clear. This condition can interrupt the communication process and there will be difficult to receive feedback from the audience (Austin \& Johnson, 2002; Banerjee \& Green, 2007; Becker, 1983; Fiske, 1990; Gibson \& Zillmann, 2000; Kress \& Van Leeuwen, 2002).

In fact, in every communication situation, people will always take care of meaning can be shared. The view from Condit (1989), Rivera-Perez (1996) and Kress \& Van Leeuwen (2002) state that is not arbitrary interpretation of the audience can make the text media, but they also need to have skills that enable they do so in certain circumstances. The situation must have an interest to them. Next, they must have the skills to understand the signs and codes in media texts representing a variety of meanings. It is clear that in the process of meaning, signs and codes vary according to media texts to be evaluated. However, previous studies did not describe the construction of meaning involves the sign and the code in the text media representing various sounds, but just focus on writing.

Normally, audience will hold on to the platform and the basic beliefs (common ground) (Clark \& Marshall, 1981; Hobbs \& Frost, 2003; Messaris, 1994), which is sharing the same knowledge. In such circumstances, communication can play its role properly. But when the presenter and recipient of the information is not held to the same platform and the basic beliefs, they need to cover the shortfall by way of discussion and understanding of meaning, which will return the value in each communication (Jakobson 1990; Jensen, 1991; Mayer, 1996; Wang, 2000; Wicks, 2005). It is clearly shows that the construction of meaning and feedback is important to avoid misinterpretation in the communication process.

In this case, the classification based on the type of media skills are important in the process of constructing meaning given that each media has its own characteristics in the form of meaning. Therefore, assessment of general construction of the meaning of the different media materials will lead to less accurate interpretation (Chesebro, 2003; Dominick, 2007). Among the more abundant material in the media nowadays are the information audio-visual materials. However, few studies that deals with audio visual equipment when compared with studies of public opinion research oriented and other audiences relatively. Most studies involving the construction of meaning is focused on material written communications. 
The study of such audio-visual media previously carried out by Buckingham (1993), Byrd-Bredbenner (2003), Compton (2006), Ferguson \& Perse (2000) and Scharrer (2005) only look at the pattern of viewing. This study is bound to the materials that related to the diversity of information technology. Instead, the study of audio-visual materials especially the meaning making that related to the technological components is rarely studied. Therefore, it is important to know how the audience in creating meaning in making interpretations on audio-visual materials related to the diversity of technology nowadays (Bernard, 2007; Buckland, 2003).

\section{Evolutionary Audience Model}

However, developments in technology resulted in the evolution of how to reach out to an audience of media in obtaining satisfaction. Technological development particularly in broadcasting has opened the attention of media practitioners to think again about their audiences that is easy to be expected especially in the interactive media environment.

Evolution model brings audiences to the new media perspective that the audience is actually determined by different practitioners and the public media before they determine their own media landscape. Thus, this case provides a different perspective and to explore the post-modern audience approaching that appears as a result of technological change and the environment. This study attempted to test the evolutionary model introduced audiences Napoli (2008) and tested the model post-modern audiences who developed the use of new media broadcasting in this country that broadcast television stations through the television web portal.

Evolutionary audience model introduced by McGannon (2008) (Figure 1) refers to the meaning of the dominant conceptual framework by industry practitioners (shareholders, (stakeholders), content publishers, distributors, advertisers, and others.) for conceptualizing the development of the audience seen in parallel with the development environment. The development of this environment is look at the transformation of technology in media and communications.

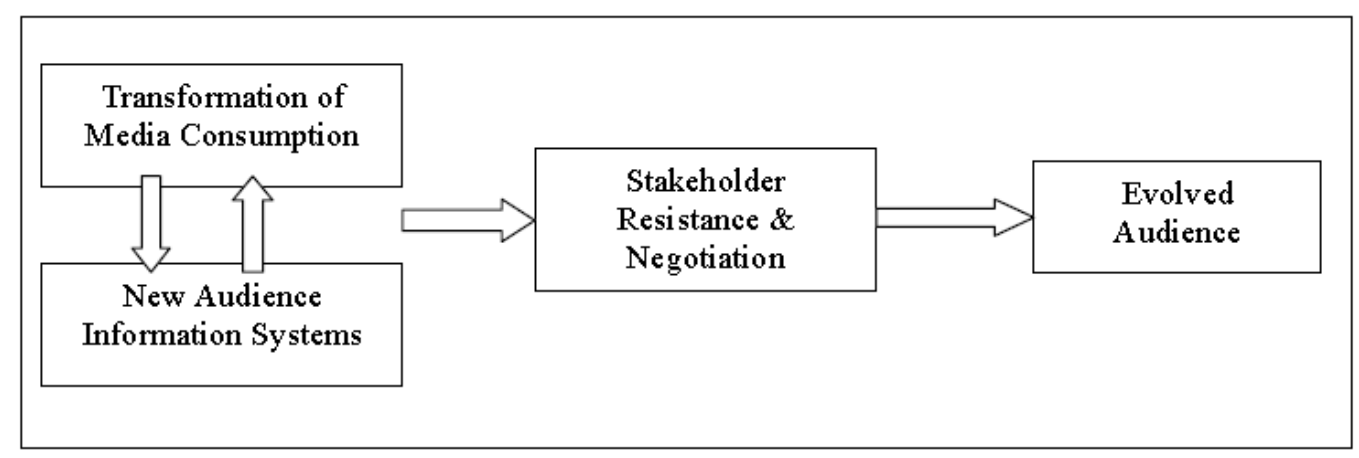

Figure 1. Evolutionary audience model (2008)

Technological developments also open attention to media practitioners to think about their audiences and indirectly construct open space for their audiences. When these changes occur, media organizations can conceptualize their own audience (Anand \& Peterson, 2000). This is caused by many media organizations tend to follow the pattern or trend in the environment for change. Changes to the public media indirectly lead to changes in the socio-cultural audiences including media literacy that allows audiences to the new media that offerings more interactive features.

Through this interactive media environment also saw the audience behavior to expose themselves to the media and gain satisfaction. This suggests that the new media audience is a malleable audience based on the development environment (Noll, 2006).

The notion of communication scholars previously thought that the audiences construction phenomenon and to determine their needs and their satisfaction on a media. However, in the evolution of media audiences in line with current technology, review of the media audience needs to be done by taking into account the aspects mentioned, such as education levels, audience behavior (experience), and also the interactive features of the new media (knowledge). Questions such as whether the audience who decides the type of media or media (practitioners) to develop and determine the audience should be evaluated again.

Changes over the time in tandem with the development of information technology, especially with the contributions that form the Internet and understanding different mindset teenagers now compared to previous 
society (Hargittai et al., 2010). With so many piles of information from the Internet and other mass media, is not known how many young people create meaning in making interpretations on a television web portal. Studies on the Internet is increasingly labeling teenagers as 'Internet literate' (see review Hargittai et al. (2010), Katz \& Sugiyama (2006) and Parker \& Plank (2000)). All these studies shown that the youngsters using the Internet as a source of current information.

Based on the issues presented, this study examine the relationship with new audience absorbs message via audio visual technology of meaning making components. To see this relationship, the most popular television web portal in Malaysia (tonton.com.my) was chosen as the subject of this study. Construction of meaning among students majoring in media and communications at the University Kebangsaan Malaysia has been formally experimental on meaning making components via audio visual technology.

\section{Methodology}

This study used experimental method as the main methodology. Thus, this situation highlights the fact of using positivism approach. Questionnaire acts as the main instrument for data acquisition work through the samples were randomly selected to represent the population. This design aims to obtain general information through the collection of comprehensive data from a population. According to Field \& Hole (2003), this method serves as a tool used in research to obtain information on the facts, beliefs, feelings and so forth.

This experimental method carried out in a closed room to avoid interference from external factors that can affect test results and this is one of the advantages of experimental method. Research without interference will be able to measure performance through manipulation of the respondents with variables by the researchers who conducted the experimental procedures. Selection of an appropriate research design will minimize the influence of variables that are not expected to produce valid results and clear. Equivalent design groups (formation of random and fair) are chosen to be used in this study. Treatment and control groups equally committed through random assignment process in which all respondents have an equitable and fair probability to be placed in any group.

Figure 2 shows the design of 'pre-test/post-test control group' which was introduced by Field \& Hole (2003) and this design are used as a reference in carrying out experiments in this study. The design of this experiment divided into two groups; control and treatment. Each was selected randomly inserted into one group. Characteristics of the respondents assessed prior to the stimulus given to the treatment group, overall, respondents from both groups need to get a similar result to the variable information technology (IT) savvy that were tested. Then, the stimulus is applied to the treatment group, while the control group not subjected to any stimulus. After the experiment, the characteristics of respondents revalued, any difference for both of these conditions will be considered as the effect of the stimulus given to the treatment group compared with the control group was not given to any stimulus. Advantages of this design are that there was a pre-test (pre-test), which ensure that respondents from both the experimental group had the same characteristics (or be able to detect if the characteristics of the respondents did not, and can be divided into the respondents to the two groups before the experiment) (Field \& Hole 2003: 78).

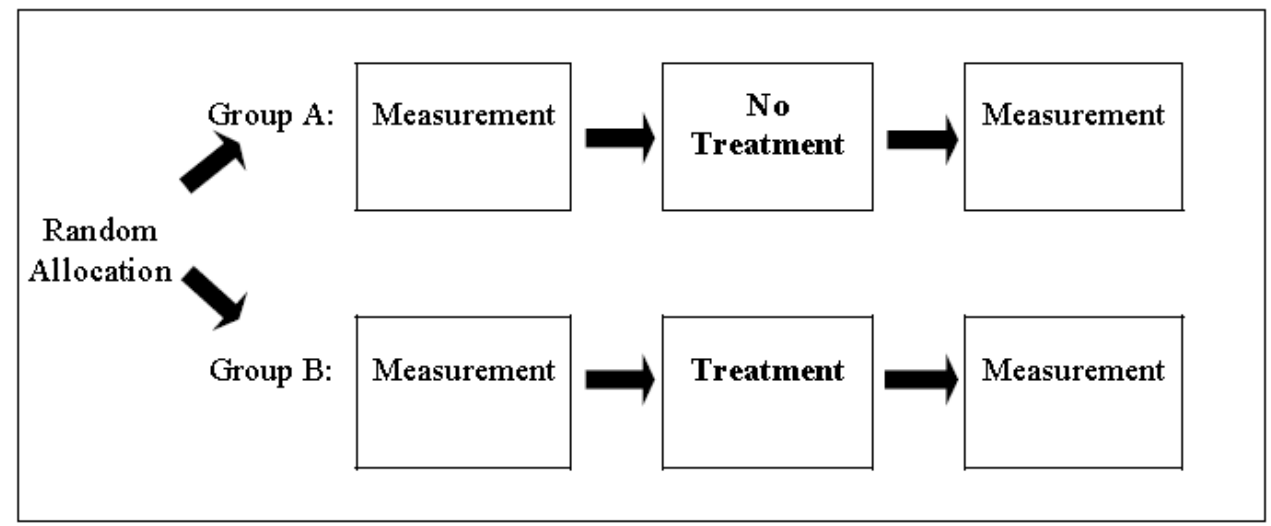

Figure 2. 'Pre-test/post-test control group' experiment design

source: (Field \& Hole 2003: 78)

Based on the experimental design, researchers have used the same way in developing and carrying out experiments in this study. Experimental design of this study is as Figure 3; 


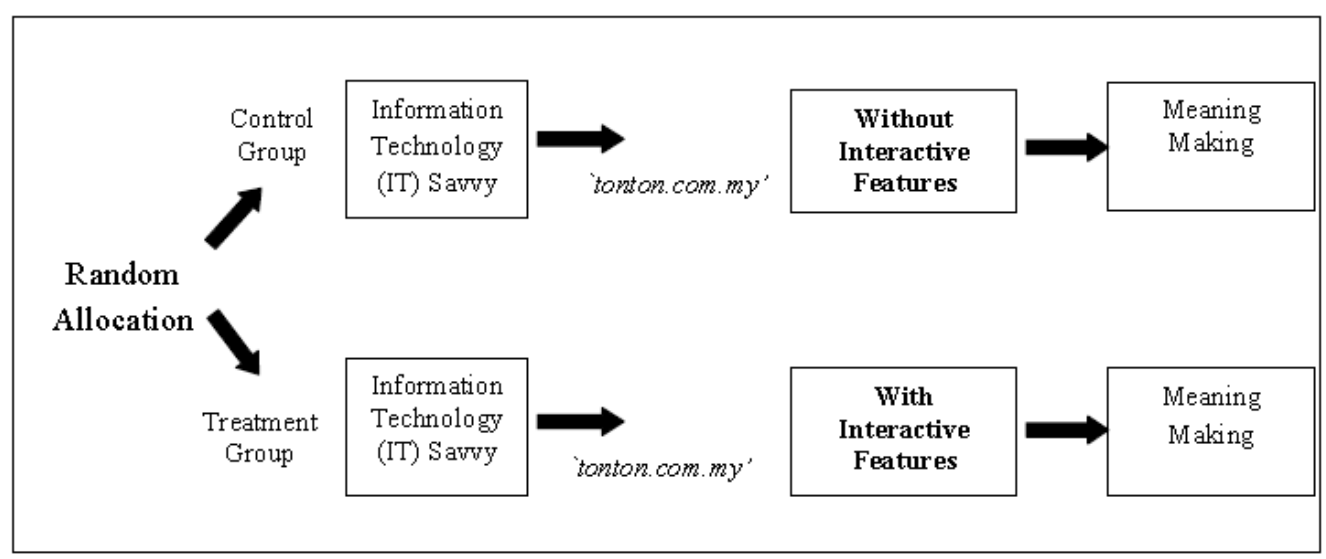

Figure 3. 'Pre-test/post-test control group' experiment design new audiences absorbs message via audio visual technology meaning making components source and adapted: (Field \& Hole, 2003: 78)

Experimental design represent that the respondents were randomly selected. Then, respondents were divided into two groups, control (40 students) and treatment (40 students). Next, respondents from both groups were tested to identify their information technology (IT) savvy of in web portal television. This test is intended to ensure that their information technology (IT) savvy in both groups were equal.

The next step, the researchers let respondents surfing 'tonton.com.my' for one hour. The control group using the manipulation original format with modification (no stimulus), while for a 'tonton.com.my' that shown to the treatment group was the original format without modification (stimulus). In the end, respondents from both groups were tested through meaning making. As a result, differences in responses between the two groups are considered as the effect of stimulation on this television web portal.

\section{Discussion and Conclusion}

Formula for the entire final research model and the control group showed that there is an equality of treatment for the time-binding factors (experience, knowledge and education) and cultural conditioning factors as the uniqueness of each individual for both control and treatment groups. Buckingham (2003), Martin-Barbero (1993), Rivera-Perez (1996) and Wood (2004) states that the audience as consumers, symbols, and they interpret events, situations, experience and active communication. Audiences also use symbols to designate, assess, respond, share experiences, ideas and feelings. Final research model control and treatment groups indicated that there were time-binding factors that represent a statement Bourdieu \& Passeron (1990), Buckingham (2003), Martin-Barbero (1993), Rivera-Perez (1996) and Wood (2004) as well as the unique effects of individual cultural conditioning. In reality, this study can detect both of these factors to the construct ion of absorbing message meaning by audiences via audio visual technology.

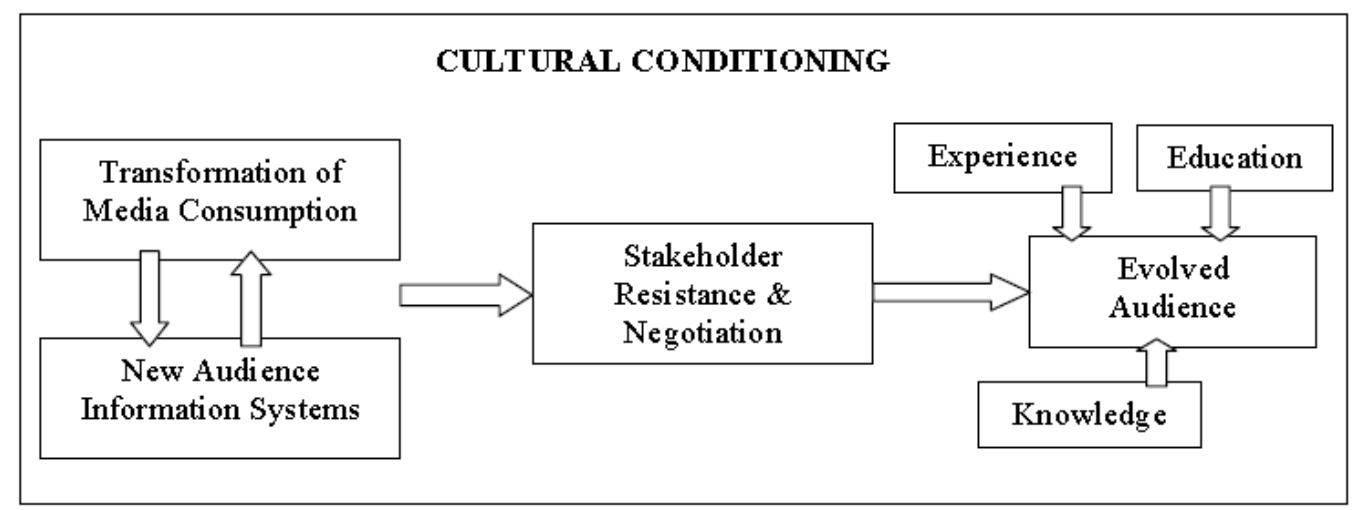

Figure 4. New audiences absorbs message via audio visual technology meaning making components model

The new audience model in figure 4 show that the time-binding factors is a combination of factors of experience, 
knowledge and education that prolonged respondents from all the information and technology changing. The experiences of these respondents were collected through reading, learning and experience of others. Meanwhile, the knowledge is learned by respondents from a variety of media whether cyber media, electronic and print media. Education was available respondents throughout their school years are exposed to the education system in Malaysia. Further, the unique factor conditioning individual culture was collected by the respondent during the course of their lives as well as information and lessons learned from family, friends and society either through formal or informal.

As a conclusion, individuals was affected by the time-binding factors (experience, knowledge and education) as well as unique cultural conditioning that they have access to a changing of technology and environment of information. Interpretation is essentially located in the social as an individual experience and knowledge to play a major role in making the interpretation. This is due to the nature of 'information' which naturally based on the socio-cognitive psychology in order to indicate a special meaning unitary, while the process of giving meaning or 'processing' suggests a set of linear singularity of meaning and transformation automatically generated from the information does not allow further to provide diversity in interpretation. Thus, Baran (2010) and Livingstone (2007) had suggested that the experience and knowledge are the elements that play an important role in meaning making.

The effect of the time-binding factors (experience, knowledge and education) that have been instilled into the soul of the respondents since childhood conditioning as well as unique factors to individuals' cultural beliefs and practices that have long held. This finding is consistent with the opinion of Baran (2010) who suggested the basic acceptance of the meaning in specific information tend to occur when groups of audience share a cultural background and interpretation of the information in a similar way.

\section{References}

Albarran, A. B. (2006). Management of electronic media (3rd ed.). Canada: Thomson Wadsworth.

Anand, N., \& Peterson, R. A. (2000). When market information constitutes fields: Sensemaking of markets in the commercial music field. Organization Science, 11, 270-284. http://dx.doi.org/10.1287/orsc.11.3.270.12502

Austin, E. W., \& Johnson, K. K. (2002). Effects of general and alcohol specific media literacy training on student's decision making about alcohol. Journal of Health Communications, 2(1), 17-42.

Badaruddin, N. B. (2002). Dunia media moden. Kuala Lumpur: PTS Publications \& Distributors Sdn. Bhd.

Banerjee, S. C., \& Greene, K. (2007). Antismoking initiatives: Effects of analysis versus production media literacy interventions on smoking-related attitude, norm, and behavioral intention. Health Communication, 22(1), 37-48. http://dx.doi.org/10.1080/10410230701310281

Baran, S. J. (2010). Introduction to mass communication theory: Media literacy and culture (6th ed.). McGraw-Hill, CA: Wadsworth Publishing Company.

Basri, F. K. H., Sarji, A., \& Yusof, A. (2004). Era digital: Cabaran baru kepada karyawan serta pendidik penyiaran dan perfileman di Malaysia. Jurnal Komunikasi, (20), 1-15.

Becker, S. L. (1983). Discovering mass communication (2nd ed.). Glenview, IL: Scott, Foresman and Company.

Bernard, S. C. (2007). Documentary storytelling: Making stronger and more dramatic nonfiction films (2nd ed.). Oxford: Elsevier Inc.

Bourdieu, P., \& Passeron, J. C. (1990). Reproduction in education, society and culture. London: Sage Publications.

Buckingham, D. (1993). Children talking television: The making of television literacy. London: Falmer.

Buckingham, D. (2003). Media education: Literacy, learning and contemporary culture. Maiden: Blackwell Publishing.

Buckland, W. (2003). Teaching yourself: Film studies. Great Britain: Hodder \& Stoughton Educational.

Bucy, E. P., \& Newhagen, J. E. (2004). Media access: Social and psychological dimensions of new technology use. Mahwah, New Jersey: Lawrence Erlbaum Associates.

Byrd-Bredbenner, C., Finckenor, M., \& Frasso, D. (2003). Health related content in prime-time television programming. Journal of Health Communication, 8, 329-341. http://dx.doi.org/10.1080/10810730305721

Chatterji, M. (2006). Technology transfer in the developing countries. London: The Macmillan Press Ltd.

Chesebro, J. W. (2003). Communication, values, and popular television series - a twenty-five year assessment 
and final conclusion. Communication Quarterly, 567-418. http://dx.doi.org/10.1080/01463370309370164

Clark, H. H., \& Marshall, C. R. (1981). Definite reference and mutual knowledge. In B. L. Webber, A. K. Joshi, \& I. A. Sag (Eds.), Elements of discourse understanding (pp. 10-63). Cambridge, UK: Cambridge University Press.

Compton, J. (2006). Serious as a heart attack: Health-related content of late-night comedy television. Journal of Health Communication, 19(2), 143-151. http://dx.doi.org/10.1207/s15327027hc1902_6

Condit, C. M. (1989). The rhetorical limits of polysemy. Critical Studies in Mass Communication, 6(2), 103-122. http://dx.doi.org/10.1080/15295038909366739

Creeber, G. (2009). Digital theory: Theorizing new media. In G. Di dalam Creeber, \& R. Martin (Eds.), Digital cultures: Understanding new media. Mc Graw Hill. Open University Press.

Dominick, J. R. (2007). The dynamics of mass communications: Media in the digital age (9th ed.). Boston: Mc Graw Hill.

Ferguson, D. A., \& Perse, E. M. (2000). The world wide web as a functional alternative to television. Journal of Broadcasting \& Electronic Media, 44(2), 155-174. http://dx.doi.org/10.1207/s15506878jobem4402_1

Fidler, R. (1997). Mediamorphosis: Understanding new media. Thousand Oaks, CA: Pine Forge Press.

Field, A., \& Hole, G. J. (2003). How to design and report experiments. London: Sage Publication Ltd.

Fiske, J. (1990). Introduction to communication studies (2nd ed.). London: Routledge.

Friedmann, A. (2001). Writing for visual media. United States of America: Focal Press.

Gibson, R., \& Zillmann, D. (2000). Reading between the photographs: The influence of incidental pictorial information on issue perception. Journalism \& Mass Communication Quarterly, 77(2), 355-366. http://dx.doi.org/10.1177/107769900007700209

Grant, C. B. (1996). Communication technology update. Boston: Focal Press. Inc.

Hargittai, E., Fullerton, F., Menchen-Trevino, E., \& Thomas, K. (2010). Trust online: Young adults' evaluation of web content. International Journal of Communication, 4, 468-494.

Harris, T. M. (2006). Visual information literacy via visual means: Three heuristics. Reference Services Review, 34(2), 213-221. http://dx.doi.org/10.1108/00907320610669452

Hobbs, R., \& Frost, R. (2003). Measuring the acquisition of media literacy skills. Reading Research Quarterly, 38, 330-355. http://dx.doi.org/10.1598/RRQ.38.3.2

Jakobson, R. (1990). Lectures on sound \& meaning. On language, 21-32.

Jensen, K. B. (1991). When is meaning? Communication theory, pragmatism, and mass media reception. Communication Year book, 14, 3-32.

Karthigesu, R. (1994). Sejarah perkembangan televisyen di Malaysia (1963-1983). Kuala Lumpur : Dewan Bahasa \& Pustaka.

Katz, J. E., \& Blumler, J. G. (1974). The uses of mass communication, current perspective on gratifications research. Beverly Hills, CA: Sage.

Katz, J. E., \& Sugiyama, S. (2006). Mobile phones as fashion statements: Evidence from student surveys in the US and Japan. New Media and Society, 8(2), 367-383. http://dx.doi.org/10.1177/1461444806061950

Kress, G. (2003). Literacy in the new media age. London: Routledge. http://dx.doi.org/10.4324/9780203164754

Kress, G., \& Van Leeuwen, T. (2002). Colour as a semiotic mode: Notes for a grammar of colour. Visual Communication, 1(3), 343-368. http://dx.doi.org/10.1177/147035720200100306

Livingstone, S. (2007). On the material and the symbolic: Silverstone's double articulation of research traditions in new media studies. New Media and Society, 9(1), 16-24. http://dx.doi.org/10.1177/1461444807075200

Martin-Barbero, J. (1993). Communication, culture, and hegemony: From the media to mediations. Newbury Park, CA: Sage.

Mayer, R. E., Bove, W., \& Tapangco, L. (1996). When less is more: Meaningful learning from visual and verbal summaries of science textbook lessons. Journal of Educational Psychology, 88(1), 64-73. http://dx.doi.org/10.1037/0022-0663.88.1.64 
Messaris, P. (1994). Visual literacy: Image, mind, \& reality. Boulder CO: Westview Press.

Mullen, L. J. (2005). Teacher-Scholar Herbert Zettl: Applied educational ideals. Journal of Broadcasting \& Electronic Media, 49(4), 521-528. http://dx.doi.org/10.1207/s15506878jobem4904_12

Napoli, P. M. (2008). Towards a model of audience evolution: New technology and the transformation of media audience. Paperwork. The Donald McGannon Communication Research Centre. New York.

Noll, A. M. (2006). The evolution of media. Lanham, MD: Rowman \& Littlefield.

Parker, B. J., \& Plank, R. E. (2000). A uses and gratifications perspective on the Internet as a new information source. American Business Review, 18(2), 43-49.

Potter, W. J. (2011). Media literacy (5th ed.). London: SAGE Publications Ltd.

Rivera-Perez, L. (1996). Rethinking ideology: Polysemy, pleasure and hegemony in television culture. Journal of Communication Inquiry, 20, 37-56. http://dx.doi.org/10.1177/019685999602000203

Ruggeiro, T. E. (2000). Uses and gratification theory in the $21^{\text {st }}$ century. Mass Communication \& Society, 6(3), 3-37. http://dx.doi.org/10.1207/S15327825MCS0301_02

Scharrer, E. (2005). Sixth graders take on television: Media literacy and critical attitudes about television violence. Communication Research Reports, 24, 325-333. http://dx.doi.org/10.1080/00036810500317714

Southwell, B. G. (2005). Information overload? Advertisement editing and memory hindrance. Atlantic Journal of Communication, 13(1), 26-40. http://dx.doi.org/10.1207/s15456889ajc1301_2

Stober, R. (2004). What media evolution is: A theoretical approach to the history of new media. European Journal of Communication, 19(4), 483-505. http://dx.doi.org/10.1177/0267323104049461

Thoman, E., \& Jolls, T. (2004). Media literacy - A national priority for a changing world. American Behavioral Scientist, 48(1), 18-29. http://dx.doi.org/10.1177/0002764204267246

Valkenburg, M. P., \& Soeters, K. E. (2001). Children's positive and negative experience with the internet : An $\begin{array}{llll}\text { exploratory } & \text { survey. } & \text { Communication }\end{array}$ http://dx.doi.org/10.1177/009365001028005004

Verser, R., \& Wicks, R. H. (2006). Managing voter impressions: The use of images on presidential candidate web sites during the 2000 campaign. Journal of Communication, 56, 178-197. http://dx.doi.org/10.1111/j.1460-2466.2006.00009.x

Wang, G., \& Shen, V. (2000). East, west, communication and theory. Searching for the Meaning of Asian Communication Theories, 10(2), 14-33. http://dx.doi.org/10.1080/01292980009364782

Whiting, G. (2001). Encouraging technological literacy in the Richmond City Schools: The standards have provided legitimacy for the teaching of elementary technology. The Technology Teacher, 61, 88-102.

Wicks, R. H. (2005). Message framing and constructing meaning: An emerging paradigm in mass communication research. In P. Kalbfleish (Ed.), Communication yearbook 29 (pp. 333-360). Mahwah, NJ: Erlbaum.

Wood, J. T. (2004). Communication mosaics: An introduction to the field of communication (3rd ed.). Belmont: Thomson Wadsworth. 